\title{
Keterlibatan Pendidikan Anak Usia Dini terhadap Fenomena Stunting di Indonesia
}

\author{
PRIMA SUCI ROHMADHENY \\ Program Studi Pendidikan Guru Pendidikan Anak Usia Dini, Universitas Ahmad Dahlan \\ Email: prima.rohmadheny@pgpaud.uad.ac.id
}

Article Received: 02-06-2018

Published Article: 06-11-2018

DOI: https://doi.org/10.29313/ga.v2i1.3795

\begin{abstract}
Stunting phenomena at early childhood in Indonesia isn't the new problem. But, this case was not solved yet maximally. The Government have been created the stunting intervention design in Indonesia, specially in the priority region with highest stunting cases. The one of intervention design which have been created and allready implemented by Indonesian Government is the sensitive nutrition intervention, two of them are the parenting education program and universal erly childhood education service. The core two of that programe could be find at Early Childhood Education service based on Integrative Holistic. Therefore, Early Childhood Education involvement on encountering stunting phenomena in Indonesia is maximzing implementation of Integrative Holistic programe on Early Childhood Education throughout Indonesia.
\end{abstract}

Keywords: Stunting, Early Childhood Education, and Integrative Holistic

\begin{abstract}
Abstrak
Fenomena kejadian stunting pada anak baduta dan balita di Indonesia bukan merupakan hal yang baru. Namun kasus ini belum juga dapat diselesaikan secara maksimal. Pemerintah telah merancang kerangka intervensi untuk mengatasi stunting di Indonesia, diutamakan pada wilayah prioritas dengan kondisi stunting terbanyak. Salah satu kerangka intervensi yang telah dirancang dan dilaksanakan oleh pemerintah adalah intervensi gizi sensitif, dua diantaranya adalah berisi program pendidikan pengasuhan (parenting education program) dan layanan PAUD yang universal. Dua pokok program tersebut dapat ditemukan pada layanan PAUD yang berbasis pada prinsip Holistik Integratif. Oleh sebab itu, keterlibatan PAUD dalam menghadapi fenomena stunting di Indonesia adalah dengan memaksimalkan penerapan prinsip Holistik Integratif secara wajib pada PAUD di seluruh Indonesia.
\end{abstract}

Kata Kunci: Stunting, PAUD, dan Holistik Integratif.

\section{Pendahuluan}

Bonus Demografi Indonesia pada tahun 2030 merupakan keuntungan bagi Indonesia, di mana kondisi jumlah penduduk yang memiliki usia produktif sangatlah besar. Akan tetapi, bonus demografi ini hanya akan menjadi sangat bermakna dan menguntungkan jika penduduk yang pada tahun 2030 memiliki kualitas yang baik. Upaya dalam membangun kualitas sumber daya manusia yang baik tentu saja dimulai sejak usia dini, karena mereka yang nantinya pada tahun 2030 memasuki usia produktif adalah mereka yang pada saat ini berada pada usia balita. Pembangunan kualitas sumber daya manusia sejak usia ini, bukan sekadar berbicara mengenai kognitifnya saja melainkan seluruh aspek perkembangan anak. Terutama pada seratus hari pertama kehidupannya, karena pertumbuhan dan perkembangan seratus hari pertama kehidupan anak sangat berpengaruh terhadap perkembangan seluruh aspeknya di kehidupan anak selanjutnya. Termasuk sejak anak masih dalam kandungan (Anuraga, 2016). 
Tantangan dalam mewujudkan kualitas penduduk yang baik sangat variatif. Salah satu tantangan yang saat ini menjadi prioritas pemerintah untuk segera diatasi adalah adanya kasus balita pendek atau stunting (Anuraga, 2016). Kasus stunting banyak terjadi pada usia baduta. Di Indonesia kasus ini menduduki peringkat 5 besar di dunia dan telah dilaporkan melalui hasil riset kesehatan dasar bahwa prosentase stunting di Indonesia tahun 2013 mencapai 37\% (Tim Nasional Percepatan Penanggulangan Kemiskinan, 2017). Jika dihitung jumlah, maka prosentase tersebut menunjukkan kisaran sebanyak 9 juta jiwa. Oleh sebab itu, kasus ini menjadi ancaman yang cukup serius bagi potensi keuntungan bonus demografi di Indonesia.

Secara garis besar, Kementerian Kesehatan Republik Indonesia menyebutkan setidaknya ada 4 kelompok besar faktor yang menjadi penyebab stunting pada anak. Faktor-faktor tersebut antara lain: (1) praktik pengasuhan yang kurang baik, (2) masih terbatasnya layanan kesehatan baik itu layanan ibu hamil, setelah melahirkan, dan pendidikan dini yang berkualitas, (3) kurangnya akses keluarga terhadap makanan bergizi, dan (4) kurangnya akses air bersih dan sanitasi (Tim Nasional Percepatan Penanggulangan Kemiskinan, 2017). Faktorfaktor tersebut merupakan hasil penelitian kementerian kesehatan Republik Indonesia yang telah dipublikasikan melaui World Bank. Dengan mengetahui faktor penyebabnya, maka kemudian pemerintah merancang suatu program intervensi.

Pelaksanaan intervensi bagi 100 kabupaten/kota yang memiliki angka prevalensi kasus stunting terbanyak merupakan program yang telah dilaksanakan oleh pemerintah pusat. Dari 100 kabupaten/ kota yang menjadi sasaran intervensi, Kabupaten Cianjur berada pada kategori yang tinggi tingkat kasus stunting dan disusul kemudian Kabupaten Bangka Belitung dan Kabupaten Sleman, Yogyakarta. Telah dilaporkan bahwa di kabupaten Cianjur ditemukan $35,7 \%$ dari 210.750 anak balita mengalami stunting, di Bangka Belitung sekitar 27,3\% dari jumlah 122.807 anak balita anak balita yang mengalami stunting, sedangkan di Kabupaten Sleman Provinsi D.I. Yogyakarta sebesar 11,9\% (mediaindonesia. com, 2018). Kondisi tersebut tentu hanya dilihat berdasarkan kondisi balita yang terdaftar dan rutin mengikuti penimbangan dan pengukuran di posyandu atau di lembagalembaga PAUD.
Berdasarkan buku ringkasan 100 kabupaten/kota prioritas mendapatkan intevensi anak stunting ditemukan informasi bahwa pemerintah melakukan beberapa upaya intervensi untuk mengatasi kasus tersebut. Intervensi tersebut dibagi dalam dua kerangka antara lain: intervensi gizi spesifik dan intervensi gizi sensitif. Kerangka intervensi gizi spesifik ditujukan bagi 1000 hari pertama kehidupan anak. Karena pemberian gizi seimbang pada 1000 hari pertama kehidupan anak dapat berkontribusi $30 \%$ terhadap penurunan stunting pada anak. Sedangkan intervensi gizi sensitif dilakukan melalui beragam program kegiatan pembangunan yang berada di luar sektor kesehatan dan bagian ini berkontribusi sebesar $70 \%$ pada intervensi stunting (Tim Nasional Percepatan Penanggulangan Kemiskinan, 2017).

Intervensi gizi spesifik meliputi: intervensi spesifik dengan sasaran Ibu hamil, intervensi gizi spesifik dengan sasaran Ibu menyusui dan anak usia 0 - 6 bulan, serta intervensi gizi spesifik dengan sasaran Ibu Menyusui dan Anak Usia 7-23 bulan. Terdapat 12 kegiatan untuk intervensi gizi sensitif yang bisa berkontribusi pada upaya penurunan stunting antara lain: (1) memberi kepastian dan ketersediaan akses yang mudah terhadap air bersih, (2) memastikan ketersediaan akses sanitasi, (3) mengadakan fortifikasi pada bahan pangan, (4) memberikan fasilitas akses untuk layanan kesehatan dan Keluarga Berencana, (5) memberikan fasilitas Jaminan Kesehatan Nasional (JKN),

(6) memberifasilitas Jaminan Persalinan Universal (Jampersal), (7) memberikan fasilitas program parenting education atau pendidikan pengasuhan bagi orang tua, (8) memberikan layanan Pendidikan Anak Usia Dini (PAUD) yang Universal, (9) memberikan edukasi tentang gizi pada masyarakat, (10) mengedukasi masyarakat tentang gizi anak, kesehatan seksual dan reproduksi pada remaja, (11) menyediakan bantuan dan jaminan sosial bagi keluarga miskin, (12) meningkatkan ketahanan pangan dan gizi (Tim Nasional Percepatan Penanggulangan Kemiskinan, 2017).

Dengan terlaksananya program intervensi, dilaporkan bahwa hasil PSG 2017 menunjukkan telah adanya penurunan jumlah baduta (bawah usia dua tahun) stunting dibandingkan tahun 2016, dari 21,7\% menjadi $20,1 \%$. Selain itu, jumlah balita kurus juga mengalami penurunan dari $11,8 \%$ pada tahun 2014 menjadi 9,5\% 
di tahun 2017 (Direktorat Gizi Masyarakat, 2018). Melalui program intervensi tersebut, khususnya pada kerangka intervensi program spesifik disebutkan bahwa dapat diwujudkan melalui peranan dan keterlibatan Pendidikan Anak Usia Dini (PAUD). Penyelenggaran layanan bagi anak usia dini di PAUD dirancang setiap awal tahun dalam suatu kurikulum untuk disajikan bagi peserta didik. Oleh sebab itu, artikel ini akan membahas secara mendalam tentang bentuk keterlibatan PAUD dalam menghadapi fenomena stunting di Indonesia.

\section{Metode Penelitian}

Penellitian ini menggunakan metode penelitian kualitatif dengan jenis studi pustaka. Penelitian ini mengkaji fenomena tentang stunting yang ditemukan dalam berbagai pemberitaan dan forum-forum diskusi kemudian menelusuri, menggali, serta melakukan analisis kritis terhadap kajian yang ditemukan pada dokumen kepustakaan dan hasil penelitian yang relevan. Simpulan hasil analisisnya dapat digunakan sebagai rekomendasi yang kuat terhadap program yang mendukung upaya menurunkan dan mengantisispasi stunting.

\section{Pembahasan}

\section{Stunting dan Faktor Penyebabnya}

Stunting merupakan kondisi pada anak balita yang gagal tumbuh akibat kekurangan gizi secara kronis dan dalam waktu yang lama, sehingga anak-anak menjadi terlalu pendek dari anak-anak seusianya. Balita yang memiliki panjang badan (PB/U) atau tinggi badan (TB/U) menurut umurnya dibandingkan dengan standar baku WHO-MGRS (Multicentre Growth Reference Study) 2006 maka akan diperoleh hasil berupa balita pendek atau stunted dan sangat pendek atau severely stunted (Direktorat Bina Gizi, 2011). Kementerian Kesehatan (Kemenkes) Republik Indonesia mendefinisikan stunting sebagai anak balita yang memiliki nilai z-score kurang dari -2SD/standar deviasi berarti stunted dan kurang dari - 3SD berarti severely stunted (Tim Nasional Percepatan Penanggulangan Kemiskinan, 2017).

Berdasarkan beberapa hasil penelitian yang telah dikaji ditemukan data bahwa faktor-faktor yang berhubungan dan atau mempengaruhi terjadinya stunting pada balita dan baduta antara lain: pendidikan ibu, pendapatan keluarga, pengetahuan ibu mengenai gizi, pemberian ASI eksklusif pada 6 bulan pertama, umur pemberian MP-ASI, faktor umur, jenis konsumsi, tingkat kehadiran ke posyandu, frekuensi sakit dan lama sakit, tingkat kecukupan zink dan zat besi, Kecukupan Vitamin A, riwayat penyakit infeksi, panjang badan lahir bayi, serta faktor genetik (Aridiyah, Rohmawati,

\& Ririanty, 2015; Hidayah \& Juffrie, 2013; Ni'mah \& Nadhiroh, 2016; Welasasih \& Wirjatmadi, 2012). Kecukupan asupan Zinc memiliki proporsi yang cukup besar dalam mempengaruhi kejadian stunting pada anak baduta atau bawah dua tahun (Aridiyah dkk., 2015; Taufiqurrahman, Hadi, Julia, \& Herman, 2009). Dengan demikian, faktor yang memicu terjadinya stunting sangat beragam, dari sejak anak masih dalam kadungan sampai dengan anak lahir.

Faktor resiko yang serupa juga ditunjukkan dari beberapa hasil penelitian pada baduta dan balita di berbagai wilayah di Indonesia seperti di Bali, Yogyakarta, Purwakarta, Nusa Tenggara Barat, Semarang, Aceh, Sulawesi, Depok, Manado, dan sebagainya (Anisa, 2012; Anugraheni \& Kartasurya, 2012; Aridiyah dkk., 2015; Bentian, Mayulu, \& Rattu, 2015; Kusuma \& Nuryanto, 2013; Lestari, Margawati, \& Rahfiludin, 2014; Meilyasari \& Isnawati, 2014; Nadiyah, Briawan, \& Martianto, 2014; Oktarina \& Sudiarti, 2014; Sulastri, 2012). Jika dicermati, maka terjadinya stunting pada sebaran wilayah tersebut tidak hanya terjadi pada wilayah dengan kondisi geografis yang sulit akses terhadap layanan kesehatan dan air bersih akan tetapi juga di wilayah yang tidak bermasalah dengan akses layanan kesehatan dan air bersih. Dengan demikian, potensi terjadinya stuting dapat di mana saja. Oleh sebab itu, di samping upaya mengatasi balita stunting juga diperlukan upaya antisipasinya secara rutin dan berkelanjutan.

\section{Prinsip Pengembangan Kurikulum PAUD}

Pemberian layanan pendidikan bagi anak usia dini, tentu tidak dapat disamakan dengan pemberian layanan pendidikan bagi anak-anak usia sekolah. Demikian pula kurikulum yang dijadikan pedoman dalam mengembangkan program kegiatan pembelajaran sehari-hari.

Kurikulum dan perencanaan pembelajaran bagi anak usia dini sama halnya 
menu makanan. Menyajikan menu makanan harus memiliki kandungan gizi yang lengkap dan seimbang. Demikian pula kurikulum yang disiapkan untuk memberi layanan bagi anak usia dini. Oleh sebab itu, dalam mengembangkan kurikulum operasional untuk anak usia dini perlu memperhatikan prinsip-prinsip pengembangan kurikulum PAUD.

Prinsip-prinsip pengembangan kurikulum PAUD telah disebutkan pada Peraturan Menteri Pendidikan dan Kebudayaan Republik Indonesia Nomor 146 Taun 2014 tentang Kurikulum 2013 PAUD lampiran III. Prinsip-prinsip tersebut terdiri dari 10 butir, antara lain: (1) berpusat pada anak, (2) kontekstual,

(3) terpadu dan berkesinambungan, (4) pembentukan sikap spiritual dan sosial anak secara utuh, (5) sesuai dengan tingkat perkembangan anak, (6) mempertimbangkan cara belajar anak, (7) holistik integratif, (8) menggunakan pendekatan belajar melalui bermain, (9) memberikan pengalaman belajar sesuai perkembangan jaman, dan (10) memperhatikan karakteristik sosial budaya anak (Republik Indonesia, 2014).

Diantara sepuluh prinsip tersebut, ada sebuah prinsip yang memuat keterpaduan antar seluruh aspek dan meliputi beberapa layanan bagi anak usia dini. Beberapa layanan tersebut terangkum dalam sebuah prinsip yang disebut dengan holistik integratif. Kurikulum yang menerapkan prinsip holistik integratif dapat dikatakan juga sebagai PAUD yang ramah anak Menerapkan program holistik integratif di lembaga PAUD tanpa diskriminasi. (Rohmadheny \& Saputra, 2018b)"abstract":"Every child possesses the same right, and it shall be fulfilled. The children possess rights to live, to grow, $\backslash r \backslash$ nto develop, and to participate fairly under the human dignity and honor. Furthermore, without exception, $\backslash \mathbf{r} \backslash$ nevery child is eligible for good education and protection from any kinds of violence and discrimination. \r $r$ nAccordingly, all education institutions in Indonesia are expected to be able to fulfill the rights of children. $\backslash r \backslash n A n$ attempt to fulfill the children' right in the school environment has been made by the Deputy of children' $\backslash r\rangle$ ngrowth and development of Ministry of Women Empowerment and Children Protection through the $\backslash \mathrm{r} \backslash$ nimplementation of ChildFriendly School (CFS.

\section{PAUD Berbasis Holistik Integratif}

Pendidikan Anak Usia Dini (PAUD) yang berbasis prinsip Holistik Integratif, berarti PAUD tersebut memberikan layanan pada peserta didik pada minimal 5 dimensi. Dimensi layanan Holistik Integratif (HI) di PAUD meliputi rangsangan pendidikan, pengasuhan, kesehatan, gizi, dan perlindungan (Direktorat Pembinaan PAUD, 2015; Republik Indonesia, 2014; Rohmadheny \& Saputra, 2018b, 2018a)"abstract":"Every child possesses the same right, and it shall be fulfilled. The children possess rights to live, to grow, $\backslash r \backslash$ nto develop, and to participate fairly under the human dignity and honor. Furthermore, without exception, \r\nevery child is eligible for good education and protection from any kinds of violence and discrimination. $\backslash r \backslash$ nAccordingly, all education institutions in Indonesia are expected to be able to fulfill the rights of children. $\backslash r \backslash n A n$ attempt to fulfill the children' right in the school environment has been made by the Deputy of children' $\backslash r \backslash$ ngrowth and development of Ministry of Women Empowerment and Children Protection through the $\backslash r \backslash$ nimplementation of Child-Friendly School (CFS. Kelima dimensi tersebut diharapkan dapat diterapkan secara utuh, sungguh-sungguh dan berkesinambungan.

Dalam menerapkan prinsip layanan HI di PAUD, baik kepala PAUD maupun guru tidak dapat bekerja sendiri. Maka dari itu, pihak lembaga PAUD harus melakukan kemitraan dengan orangtua dan institusi lain agar kegiatan-kegiatan yang direncanakan pada semua dimensi tersebut dapat terlaksana dengan maksimal.

Kerjasama mitra dapat dilakukan dengan tenaga kesehatan, puskesmas, posyandu, klinik, psikolog, konselor, ahli gizi, dsb. Kerjasama mitra tersebut tentu disesuaikan dengan kebutuhan layanan. Mitra dapat dihadirkan atau juga peserta didik yang dirujuk.

\section{Keterlibatan PAUD dalam Mengha- dapi Fenomena Stunting}

Kemitraan Satuan PAUD dengan orangtua dan instansi lain yang relevan akan sangat mendukung keberhasilan tujuan pelaksanaan program. Terutama dalam hal yang berkaitan erat dengan upaya menurunkan tingkat stunting anak balita dan mengantisipasinya. Satuan PAUD merupakan jenjang pendidikan yang memiliki ragam program layanan antara lain: TPA (Taman 
Penitipan Anak)/ Daycare, KB (Kelompok Bermain)/ Playgroup, TK (Taman Kanakkanak), dan sebagainya. Semua program tersebut merupakan layanan yang sangat mungkin untuk dapat menerima layanan bagi anak sejak lahir sampai dengan 6 tahun. Oleh sebab itu, PAUD memiliki peran penting dalam berkontribusi mengantisipasi dan menurunkan tingkat stunting pada anak balita.

Peran dan keterlibatan PAUD dalam menghadapi fenomena stunting pada anak di Indonesia dapat melalui penerapan PAUD berbasis Holistik Integratif (HI) secara maksimal. Pada dimensi layanan kesehatan dan gizi dalam program HI, Satuan PAUD memerlukan kemitraan dengan berbagai mitra, salah satunya tenaga medis terdekat. Program yang umumnya dapat dilakukan dalam dimensi ini beragam.

Pada dimensi layanan kesehatan, Satuan PAUD dapat menjalankan program pembiasaan cuci tangan dengan air mengalir dan sesuai prosedur 7 langkah cuci tangan. Selain itu, menjaga lingkungan dan alat main yang bersih dan sehat pun merupakan bagian dari dimensi ini. Pemberian imunisasi yang sesuai dapat dilakukan melalui kerjasama dengan bidan di posyandu terdekat, puskesmas, maupun klinik.

Selain itu, satuan PAUD juga dapat mengadakan kegiatan screening test di awal masuk atau awal tahun ajaran dan rutin melakukan penimbangan berat badan, tinggi badan, lingkar kepala, dan lingkar lengan peserta didik. Hal-hal tersebut dilakukan sebagai upaya deteksi dini tumbuh kembang yang merupakan salah satu komponen yang diperlukan dalam menyusun kurikulum (Republik Indonesia, 2014). Apabila dari hasil tersebut ditemukan suatu permasalahan, maka guru dapat duduk bersama orangtua untuk mendiskusikan cara mengatasinya. Jika diperlukan, maka dapat segera dirujuk pada ahli agar segera mendapat intervensi yang tepat.

Pada dimensi pengasuhan, satuan PAUD dapat menyelenggarakan program parenting education bagi para orangtua/ walimurid secara rutin dan berkala dengan topik-topik yang disesuaikan dengan kebutuhan. Topik yang dibahas bersama para orangtua dapat berupa kesehatan, gizi, rangsangan pendidikan, dan perlindungan bagi anak-anak.

Kemitraan dengan keluarga dan masyarakat sebagai bagian dari tripusat pendidikan pun akan dapat mendukung keterlaksanaan program HI secara maksimal. Program HI juga sejalan dengan program dari Kementerian Pendidikan dan Kebudaayaan Direktorat Pendidikan Keluarga tentang pelibatan keluarga dalam pendidikan, karena keluarga merupakan pendidik yang pertama dan utama (Wahy, 2012). Seluruh program tersebut harus dilaksanakan secara sistematis dari mulai perencanaan, pelaksanaan, monitoring dan evaluasi, hingga pelaporan kepada pihak-pihak yang terkait.

\section{Kesimpulan}

Berdasarkan hasil pembahasan di atas, maka dapat ditarik kesimpulan bahwa satuan PAUD memiliki peran penting dalam menyukseskan upaya antisipasi dan penuruan tingkat stunting pada anak baduta dan anak balita di Indonesia. Bentuk keterlibatan PAUD dalam upaya tersebut adalah dengan mengoptimalkan penerapan program PAUD berbasis Holistik Integratif.

Optimalisasi dalam penerapan program PAUD berbasis holistik integratif dapat direkomendasikan kepada seluruh layanan PAUD. Harapannya, dengan mengiptimalkan layanan PAUD Holistik Integratif maka PAUD dapat berkontribusi terhadap upaya antisipasi dan penurunan tingkat stunting di Indonesia.

\section{Daftar Pustaka}

Anisa, P. (2012). Faktor-Faktor Yang Berhubungan Dengan Kejadian Stunting Pada Balita Usia 25-60 Bulan Di Kelurahan Kalibaru Depok Tahun 2012. Universitas Indonesia.

Anugraheni, H. S., \& Kartasurya, M. I. (2012). Faktor risiko kejadian stunting pada anak usia 12-36 bulan di Kecamatan Pati, Kabupaten Pati (PhD Thesis). Diponegoro University.

Anuraga, A. L. (2016) . Stunting, Prioritas Utama Masalah Gizi Indonesia . Diambil 31 Mei 2018, dari https:// w w w . c n n i n d o n e s i a. c o m / g a y a hidup/20160218202959-255-111943/ stunting-prioritas-utama-masalah-giziindonesia

Aridiyah, F. O., Rohmawati, N., \& Ririanty, M. (2015). Faktor-faktor yang Mempengaruhi Kejadian Stunting pada Anak Balita di Wilayah Pedesaan dan Perkotaan (The Factors Affecting Stunting on Toddlers 
in Rural and Urban Areas). Pustaka Kesehatan, 3(1), 163-170.

Bentian, I., Mayulu, N., \& Rattu, A. J. M. (2015). Faktor Resiko Terjadinya Stunting Pada Anak TK Di Wilayah Kerja Puskesmas Siloam Tamako Kabupaten Kepulauan Sangihe Propinsi Sulawesi Utara. JIKMU, 5(1).

Direktorat Bina Gizi. (2011). Keputusan Menteri Kesehatan Republik Indonesia Nomor 1995/MENKES/SK/XII/2010 Tentang Standar Antropometri Penilaian Status Gizi.

Direktorat Gizi Masyarakat. (2018). Buku Saku Pemantauan Status Gizi. Kementerian Kesehatan Republik Indonesia.

Direktorat Pembinaan PAUD. (2015). NSPK: Petunjuk Teknis Penyelenggaraan PAUD Holistik Integratif di Satuan PAUD. Kementerian Pendidikan dan Kebudayaan Republik Indonesia.

Hidayah, F., \& Juffrie, M. (2013). ASI Eksklusif Sebagai Faktor Risiko Kejadian Stunting Pada Anak Usia 6-24 Bulan Di Kota Yogyakarta (PhD Thesis). Universitas Gadjah Mada.

Kusuma, K. E., \& Nuryanto, N. (2013). Faktor risiko kejadian stunting pada anak usia 2-3 tahun (Studi di Kecamatan Semarang Timur) (PhD Thesis). Diponegoro University.

Lestari, W., Margawati, A., \& Rahfiludin, Z. (2014). Faktor risiko stunting pada anak umur 6-24 bulan di kecamatan Penanggalan Kota Subulussalam Provinsi Aceh. Jurnal Gizi Indonesia, 3(1), 37-45.

mediaindonesia.com. (2018, Maret 12). Kasus Stunting seperti Fenomena Gunung Es. Diambil 31 Mei 2018, dari http:// mediaindonesia.com/read/detail/149073kasus-stunting-seperti-fenomena-gununges

Meilyasari, F., \& Isnawati, M. (2014). Faktor risiko kejadian stunting pada balita usia 12 bulan di Desa Purwokerto Kecamatan Patebon, Kabupaten Kendal (PhD Thesis). Diponegoro University.

Nadiyah, N., Briawan, D., \& Martianto, D. (2014). Faktor Risiko Stunting pada Anak Usia 0-23 Bulan di Provinsi Bali, Jawa Barat, dan Nusa Tenggara Timur. Jurnal
Gizi dan Pangan, 9(2).

Ni'mah, K., \& Nadhiroh, S. R. (2016). Faktor Yang Berhubungan Dengan Kejadian Stunting Pada Balita. Media Gizi Indonesia, 10(1), 13-19.

Oktarina, Z., \& Sudiarti, T. (2014). Faktor Risiko Stunting Pada Balita (24-59 Bulan) Di Sumatera. Jurnal Gizi dan Pangan, 8(3).

Republik Indonesia. (2014). Peraturan Kementerian Pendidikan dan Kebudayaan Nomor 146 Tahun 2015 tentang Kurikulum 2013 PAUD.

Rohmadheny, P. S., \& Saputra, W. N. E. (2018a). Indikator Pengukuran Kemampuan Guru Ramah Anak pada Satuan PAUD.

Rohmadheny, P. S., \& Saputra, W. N. E. (2018b). Integrative-Holistic Program: a Manifestation of CFS (Child-Friendly School) Implementation in Early Childhood Education Institution. Diambil dari http://publikasiilmiah.ums.ac.id/ handle/11617/10196

Sulastri, D. (2012) . Faktor Determinan Kejadian Stunting Pada Anak Usia Sekolah Di Kecamatan Lubuk Kilangan Kota Padang. Majalah Kedokteran Andalas, 36(1), 39-50.

Taufiqurrahman, T., Hadi, H., Julia, M., \& Herman, S. (2009). Defisiensi Vitamin A dan Zinc Sebagaifaktor Risiko Terjadinya Stunting pada Balita di Nusa Tenggara Barat. Media Penelitian dan Pengembangan Kesehatan.

Tim Nasional Percepatan Penanggulangan Kemiskinan. (2017). Buku Ringkasan Stunting: 100 Kabupaten/Kota untuk Prioritas Anak Kerdil (Stunting). Sekretariat Wakil Presiden Republik Indonesia. Diambil dari http://www. tnp2k.go.id/images/uploads/downloads/ Buku\%20Ringkasan\%20Stunting-1.pdf

Wahy, H. (2012). Keluarga sebagai basis pendidikan pertama dan utama. Jurnal IImiah DIDAKTIKA, 12(2).

Welasasih, B. D., \& Wirjatmadi, R. B. (2012). Beberapa faktor yang berhubungan dengan status gizi balita stunting. Public Health, 8(3), 15-20. 